\title{
Javanese Women's Efforts to Face Patriarchal Culture in the Novel Para Priyayi by Umar Kayam
}

\author{
Haalin Mawaddah; Suyitno; Raheni Suhita \\ Indonesian Language Education Master Program, Sebelas Maret University of Surakarta, Indonesia
}

http://dx.doi.org/10.18415/ijmmu.v8i1.2267

\begin{abstract}
This study analysed the problems caused by the patriarchal culture and the Javanese women's effort to get their existence in society. The novel Para Priyayi by Umar Kayam was one of the literary works that was thick with Javanese culture. This study used the theory of existentialist feminism Simone de Beauvoir (De Beauvoir, 1949). The result of this research was the Javanese female characters in the novel Para Priyayi by Umar Kayam experienced injustice due to the patriarchal culture. However, Javanese women leaders made efforts, so they could bring out their existence in the private and public. The existence raised by Javanese female figures in the form of women can become someone who can become an intellectual woman.
\end{abstract}

Keywords: Javanese Women; Patriarchy; Feminism Existentialism

\section{Introduction}

In essence, God creates both male and female humans as perfect creatures. When a person was born in the world, God gives nature in every human being. The nature of men and women is different. Men have sperm, jakala (kala menging) while by nature women give birth, breastfeed, has ovum (Fakih, 2013: 8). In fact, people often have misperceptions and cannot distinguish between nature and gender roles. For example, the assumption is the women's responsibility to take care of the house and educate children. The existence of these conditions causes the emergence of a perspective that men are strong, active, and rational beings, whereas women are weak, passive, and irrational(Bennett \& Royle, 2016: 168).

The issue of gender roles is still taboo in society, especially in Javanese society. It is caused Javanese society stick to a patriarchal culture which indirectly harms women a lot. The existence of patriarchy results in the position of women as marginal and subordinate creatures. Through his research, (Suryadi, 2019: 270)explains that basically Javanese women basically have strength which is described through their actions, thoughts, and strong views. When viewed from the culture, Javanese women are known as weak but strong figures. This weak nature is reflected in one of the ways in which words are soft, calm, and polite. In fact, behind the weaknesses of Javanese women, there are strengths that men do not have. For example, when a husband gets an accident, as a wife she must be willing to be cancut tali 
wanda(means: being cooperative, not just sit back and do nothing). Her willingness nrimo ing pandum (means:accept everything without demanding) to suffer not for herself but for the sake of others is one of the reference points for the greatest strength that Javanese women have (Handayani \& Novianto, 2004: 139).

The issue concerning patriarchy is one of the problems that still occur today. The impact of the problem causes injustices such as early marriage and educational disparities, especially for women. Javanese women in fact live in a society where the majority adhere to a patriarchal culture. Since childhood, Javanese women have been indoctrinated to be able to take care of the household and do not need high school. The patrilineal kinship system of Javanese society causes an asymmetrical relationship between men and women, especially in the social, for example, women should not go beyond men (Arvianti, 2011: 114). The following table was provincial data in Indonesia regarding the marriage of women aged $<18$ years which was published by PUSKAPA (Center for Study and Advocacy for the Protection and Quality of Life of Children, University of Indonesia) in 2020.

Table 1: Percentages of Women Aged 20-24 by Age of Marriage and Reasons for Quitting School, 2017

\begin{tabular}{|c|c|c|c|c|c|c|c|c|c|c|c|}
\hline $\begin{array}{l}\text { First } \\
\text { Marriage } \\
\text { Age }\end{array}$ & $\begin{array}{l}\text { Still in } \\
\text { school }\end{array}$ & $\begin{array}{l}\text { No } \\
\text { school } \\
\text { fees }\end{array}$ & $\begin{array}{l}\text { Work/ } \\
\text { Earn a } \\
\text { living }\end{array}$ & Married & $\begin{array}{l}\text { Doing } \\
\text { househ } \\
\text { old }\end{array}$ & $\begin{array}{l}\text { Feeling } \\
\text { enough } \\
\text { education }\end{array}$ & $\begin{array}{l}\text { Shame on } \\
\text { the less } \\
\text { economy }\end{array}$ & $\begin{array}{l}\text { Going } \\
\text { to } \\
\text { Distant } \\
\text { school } \\
\end{array}$ & $\begin{array}{c}\text { isabilit } \\
\text { y/Disab } \\
\text { ilities } \\
\end{array}$ & thers & otal \\
\hline $\begin{array}{l}\text { Age of first } \\
\text { marriage }<18 \\
\text { years }\end{array}$ & 5,74 & 14,69 & 8,31 & 47,90 & 17,15 & 2,48 & 0,50 & 1,13 & 0,12 & 1,99 & 100,0 \\
\hline $\begin{array}{l}\text { Age of first } \\
\text { marriage }\end{array}$ & 10,11 & 113,07 & 110,18 & 442,10 & 116,31 & 55,51 & 0,34 & 00,39 & 00,13 & 11,85 & 100,0 \\
\hline $\begin{array}{l}18+\text { years } \\
\text { Single }\end{array}$ & 4,94 & 4,87 & 30,54 & 0,00 & 1,70 & 12,94 & 0,43 & 0,44 & 1,08 & 3,04 & 100,0 \\
\hline Total & 1,93 & 4,15 & 20,07 & 21,87 & 9,16 & 8,85 & 0,41 & 0,50 & 0,60 & 2,46 & 100,0 \\
\hline
\end{tabular}

Source: PUSKAPA(UNICEF Indonesia et al., 2020)

According to PUSKAPA (UNICEF Indonesia et al., 2020) data in 2017, the percentage of age at first marriage <18 years, women in Indonesia reached $47.90 \%$ while the reasons for quitting school (doing household, having no money, feeling enough education, going to distant school, earning a living) was $\pm 44.26 \%$. For the percentage in Java, the percentage of women aged 20-24 who experienced early marriage $<18$ years old, it reached $37.01 \%$ in 2018 . This proved that the impact of a patriarchal culture was still disadvantageousfor the women. According to the data above, the column of married at age> 18 years oldwas the highest percentage. The results of social and patriarchal construction have an effect on the existence of early marriage which ultimately limits women's freedom because of their status as a wife (Sakina \& A., 2017: 74).

The patriarchal culture in Java can be seen through literary works, one of which is the novel by Umar Kayam. This research used novelPara Priyayi by Umar Kayam, which mostly described Javanese women lives. Through the novel Para Priyayi by Umar Kayam, the researcher analysed the form of patriarchy and the Javanese women's effort in dealing with this patriarchal culture. Umar Kayam is a writer, humanist, writer, who was born on April 30, 1932 in Ngawi, East Java Province. He is known to the public, one of which is his role as Bung Karno in the big screen film Pengkhianatan G $30 \mathrm{~S} \mathrm{PKI}$. His works are a novelette (short novel) entitled Sri Sumarah (1975), which contains a collection of short stories (Seribu Kunang-Kunang di Manhattan, Istriku, Madame Schultz, dan Sang Raksasa, Sybil, Secangkir Kopi dan Sepotong Donat, Chief Sitting Bull,There Goes Tatum, Musim Gugur Kembali 
di Connecticut, Kimono Biru buat Istri, Sri Sumarah, Bawuk), novel entitled Para Priyayi (1992) and Jalan Menikung (2002)

Research on patriarchal culture in Java has been conducted by several previous researchers for exampleAsri's research(2014), Sudarso et al., (2019), and Wiyatmi (2010).The theory used to answer the problems in this study was the theory of existentialist feminism. Beauvoir(De Beauvoir, 1949: 767) reveals that many women have a superior spirit and ambition. Without realizing it, this makes women trapped in their narcissism. Finally, women believe that they are an object and there will be an ego. The ego will emerge when this consciousness is the object of reflection (Medhidhammaporn, 1995: 31). That is, narcissism is formed on the basis of the nature of the female ego which eventually causes an obsession with her. Friedan (1979: 70)shows in America, the image of women in the public is designed only as an asset of a company. Based on these, women cannot arise to know their selves and new identity to form a new image too.

Woman's thought like this is not a construction made by her. Women can build her up not because of the essence of femininity that can create an existing identity. The obstacle for woman to build herself is patriarchy. The peak of woman's freedom towards her is when she became an object and a target, which means that she has to let go of a sovereign subject (De Beauvoir, 1949: 815). At least there is strategy for women to transcendence that is woman can be a worker, intellectual, and can work to gain social transformation(De Beauvoir, 1949: 848-857).

\section{Research Method}

This research was a descriptive qualitative research. This research used feminist approach. Feminism in literary texts can be studied with data called primary data (Nurgiyantoro, 2015: 111). Primary data in this research was novelPara Priyayiby Umar Kayam, while the secondary data sources were journals, reference books, and research articles. Secondary data sources were used as reference material in research. The data collection technique in this study used literature study. After the researcher collected the data, then she analysed the data using an interactive model (model analysis). Milles \& Huberman(Miles et al., 2014: 31)reveal 4 steps that can be done with this model. First, data collection which was collecting data on the novel Para Priyayi by Umar Kayam and then the data was recorded in the form of a data card. Second, data condensation by focusing or simplifying the data that had been previously collected became simpler. Third, data display, at this stage the researcher produced writing in the form of a description to answer the problems in the research. Fourth, drawing a conclusion based on the data and research results that had been done.

\section{Results and Discussion}

Feminism is a form of effort for women to bring themselves to have an equal position with men. Patriarchal culture is one example of the manifestation of forms of injustice that burden women. The impact of patriarchy in Java causes social problems in society, namely early marriage and low education for women. In addition, the feminine role of being a wife and mother can also be a problem regarding freedom for women (Tong transleted by Prabasmoro, 1998: 270). Through the feminist movement, it can help women to show their existence in society, especially Javanese women. This can be proven through the efforts of the female character in the novel Para Priyayi by Umar Kayam to face social construction in society. 


\section{Impact of Patriarchal Culture}

Javanese people believe that the highest achievement of Javanese woman is when she becomeswife who always servesher husband. The word "wanita" (means: woman) which meanswani ing tata (means: dare to be controlled) is a noble concept that reflects Javanese women who dare to control and be controlled. In the novel Para Priayi by Umar Kayam there was a female character named Aisyah or commonly called Dik Ngaisyah. Ngaisyah was a Javanese woman of priyayi(means: elite people) descent who was married to Sastrodarsono.

Dik Ngaisyah, alhamdulillah adalah istri yang saya harapkan semula. Ia adalah perempuan yang, agaknya, memang sudah disiapkan orang tuanya untuk menjadi istri priyayi yang mumpuni, lengkap akan kecakapan dan keprigelannya. Di dapur ia tidak hanya tahu memasak, tetapi juga memimpin para pembantu di dapur. Wibawa kepemimpinannya dalam pekerjaan mengatur rumah sangat terasa (Kayam, 2000: 45).

Dik Ngaisyah, thank God it is the wife I have hoped for. She is a woman whose parents apparently have prepared her to become the wife of a priyayimumpuni (means: capable of doing job well), complete with skill. In the kitchen, she does not only know how to cook, but also leads the servants in the kitchen. Her leadership authority in the work of managing the house is very noticeable(Kayam, 2000: 45).

Bukankah itu pembagian kerja antara saya dan bapak mereka? Bapak sudah membanting tulang mencari nafkah, saya yang ada digaris belakang untuk mengurus semuanya yang ada dalam keadaan beres. Kalau sampai tidak beres bapake tole bingung dan marah-marah, bis akacau dia kerja (Kayam, 2000: 226).

Isn't that the division of labour between me and their father? Father has worked hard to make a living: I am the one in the back line to take care of everything well. If it goes wrong, my husband will confused and angry of this work (Kayam, 2000: 226).

After graduated from school, Ngaisyah was married to Sastrodarsono who worked as a teacher. Ngaisyah was the only child descended from Javanese priyayi. Like Javanese woman figure in general, Ngaisyah was a patient, refined and gentle woman.After marrying Sastrodarsono, Ngaisyah devoted herself as an obedient and respectful wife to her husband. She was responsible for her position in the household to be a mother and wife who was patient and careful in managing the household. However, Ngaisyah's patient character sometimes prevented her husband from giving her the opportunity to take care of outside the house.

On that quotation, it was clear that her husband wanted his wife to be competent in handling the household. Sometimes, Javanese women get the stigma that their duties are macak, manak, masak (means: applying makeup, giving birth, and cooking). This means that when women enter the world of marriage, they have to be able to become wives and mothers who can take care of themselves, take care of their children, and take care of the house. Things like this cause the freedom of women to be restricted. They are required to carry out their feminine roles perfectly. After marriage, Javanese women become konco wingking (means: be a companion to their husbands) and when they have children they must set a good example for their children. Men who have masculine characteristics are given the position as head of the household, and wives as companions (Budiati, 2010: 58). As well as (Rokhimah et al., 2014: 141) asserts that formation of doctrine traditionally by society and environment has unintentionally contributed to be patriarchy. 
In society, Javanese women still feel that they have a position below men. Often, public does not pay enough attention to women's actions and decisions. On the other hand, all decisions are in the hands of men, women are only as fellows. Such an illustrationwas experienced by the character Mbok Yem in the novel Para Priyayi by Umar Kayam.

Inggih, Ndoro. Saya akan ikut saja. Sekali lagi maturnuwun, terima kasih banyak sekali.

Tapi begini, ya Yem.

Bagaimana, Ndoro.

Nama anakmu akan kami ganti. Wage rasanya kok kurang pantes buat anak sekolah.

Saya usul namanya diganti Lantip. Lantip artinya cerdas, tajam otaknya. Bagaimana?

Saya ikut saja kemauan, Ndoro.

Begitulah perintah dari sang kepala rumah tangga Sastrodarsono (Kayam, $2000: 21$ ).

Inggih, Ndoro (means: Yes, Madam/Sir). I'll just go along. Once again, thank you very much.

But, well, yes Yem.

How, Ndoro (means:Madam/Sir).

Your child's name will be changed. Wage, it doesn't feel right for school children. I suggest that the name will be changed to Lantip. Lantip means intelligent, sharp brain. How?

I just follow your will, Ndoro (means:Madam/Sir).

That was the order of the household head Sastrodarsono(Kayam, 2000: 21).

Mbok Yem was a female figure who wasdescribed as a widow. She worked as a tempe seller and had a son named Wage. Sastrodarsno and Ngaisyah intended to make Wage their son. In addition, Wage would be sent to school by Sastrodarsono until he graduated and got an established job. As a mother, Mbok Yem constantly accepted that it was good for her child's future. Until she changed the name from Wage to Lantip, Mbok Yem accepted.

The illustration above illustrated that Javanese women wasconstantly on sumarah(means: accept the faith)with condition. Women are considered as inferior creatures that can be a gap for men to lead them. The control of men over women's bodies causes women to become weak creatures (Kurnianto, 2016: 166). In the illustration of the novel Para Priyayi by Umar Kayam, women cannot take part in making decisions. (Putri \& Nurhajati, 2020: 82)conducted research on women in Surakarta, Central Java and obtained the results that there were several married couples who carried out deliberations in making decisions. In addition, some women tend to be passive and tend to obey their husbands decisions even though their educational backgrounds are equal. This happens because Javanese women are accustomed to nrima (means: accept) under any conditions.

The patriarchal culture causes Javanese women to become subordinated and underdogs. Women are not given the freedom to express themselves, especially in the public sphere, while men are given the freedom to do this because they are considered more capable. The stereotype of women does not need to go to high school because in the end they will only manage the domestic, which is one of the reasons why women are underdogs (Budiati, 2010: 56). The division of roles between men and women makes the position of women to be lower. The illustrationof this happened to the character Seomini in the novel Para Priyayi by Umar Kayam.

Alah, Paak, Pak. Wong anak baru kelas lima HIS kok sudah dibayangkan hari kawinnya. Genduk Mini itu baru dua belas tahun, lho Pak.

Eh lho! Kita rak harus siap mulai sekarang to, Bune. Cari jodoh yang baik buat anak kita dan keluarga kita rak tidak gampang. Kamu kira orang-tua kita dulu waktu mau menjodohkan kita terjadi dalam waktu yang cepat apa! Kalau tidak salah cukup lama lho (Kayam, 2000 : 67). 
Well, sir. Our child has just beenin fifth grade HIS, How come you imagine her wedding day. Genduk Mini(means: our little daughter) is only twelve years old, sir.

Eh, we rak (means: must) be ready from now, Bune (means: call for mother). Finding a good mate for our children and our families is not easy. Do you think our parents want to match us in quick time! If I'm not mistaken, it's been quitelong(Kayam, 2000: 67).

Saya dan istri saya sepakat menjajagi kemungkinan itu. Nampaknya dia adalah calon yang cocok untuk Genduk Mini (Kayam, 2000 :68).

My wife and I agreed to explore that possibility. He seems to be a right candidate for Genduk Mini(Kayam, 2000: 68).

Soemini wasachild of Sastrodarsono and Ngaisyah. She was the only daughter in the Sastrodarsono's family. After graduated from HIS elementary school, his parents intended to matchher with the police. Soemini's parents didnot want their child to find a mate, so they intended to match Soemini with the man of their choice. In addition, Sastrodarsono didnot want his daughter to be single for a long time, so he hadthought about Soemini's marriage since Soemini was still attending elementary school at HIS.

Low education and early marriage are serious problems often faced by Javanese women. Customs and economic problems are the reasons for Javanese women to marry early (Tsany, 2017: 87). What Soemini experienced in the novel Para Priyayi by Umar Kayam is a tradition or custom of his parents who want to find a mate for Soemini. The stereotype against Javanese women is that girls should get married as soon as possible so as not to become 'old maidens'. In addition, it is better for women who are already classified as young adult to marry immediately so that things that can harm women do not occur, one of which is sexual harassment. Through the institution of marriage, the patriarchal society thinks that this institution can be a moral guard because this institution is the only one that legalizes sexual activity (Pranowo, 2013: 84).

Early marriage can bebounded women to develop in social, educational, health and mental aspects (Tsany, 2017: 87). This statement is appropriate with the illustration that is told in the novel Para Priyayi by Umar Kayam. Apart from matching Soemini with the police, Sastrodarsono wanted his daughter not to continue schooling to high school level.

Sepintar-pintar Soemini dia itu anak perempuan.

Pada akhirnya, dia harus kawin dan membangun keluarga, membesarkan anak, membuat suaminya, dan keluarganya bahagia.

Mau sekolah apalagi dia? Pengetahuan yang dimilikinya sudah lebih dari cukup untuk

mendampingi suaminya nanti. Dan kecerdasan serta kepintaran Soemini suami mana yang tidak akan merasa beruntung (Kayam, 2000 : 67).

As smart as Soemini, she is a girl.

In the end, she has to get married and raise a family, raise children, make her husband and family happy.

What else does she go to school? The knowledge she has is more than enough to accompany her husband later. And Soemini is intelligent, which husband will not feel lucky (Kayam, 2000: 67).

Sastrodarsono wanted her daughter not to go to high school because later she would focus on her husband, children and household too. Sastrodarsono thought that girl should not be more than husband, and according to him, Soemini's knowledge during elementary and junior high school education at HIS 
was more than sufficient. According to him, taking care of the household properly was more than enough to become a mother and wife.

The quote above described a patriarchal culture that harms women, one of which was freedom to obtain the right to education. Conventionally, the family is considered the centre of women's lives and determinants of gender inequality (Walby, 1990: 61). As a result of patriarchy, Javanese society glorifies the position of man and makes him superior being. On the other hand, woman becomes creature that is inferior and secondary to one of them in education. Sudarso et al., (2019: 9)research in the East Java, most women cannot continue their education because their parents do not support them to go to school. Society does not consider thatit is necessary to provide high education to girls because women are considered good when they obey their parents' decisions. Javanese manners are highly respected by Javanese people, so that parents have an important role in the family. Oppression and underdevelopment are manifestations of this discrimination(Urifatulailiyah, 2017: 1487).

\section{The Existence of Javanese Women in Patriarchal Culture}

(Tong transleted by Prabasmoro, 1998: 282) realizes that women carry a heavy burden, but this can be removed through collective efforts, both large and small. The existence of a patriarchy culture prevents Javanese women from being recognized for their existence. However, it does not merely make women obey the existing rules. This can be proven by the actions and efforts of the female characters in Umar Kayam's novel Para Priyayi to bring out their existence in a patriarchal culture.

Dik Ngaisyah, alhamdulillah adalah istri yang saya harapkan semula. Ia adalah perempuan yang, agaknya, memang sudah disiapkan orang tuanya untuk menjadi istri priyayi yang mumpuni, lengkap akan kecakapan dan keprigelannya. Di dapur ia tidak hanya tahu memasak, tetapi juga memimpin para pembantu di dapur. Wibawa kepemimpinannya dalam pekerjaan mengatur rumah sangat terasa (Kayam, 2000: 45).

Dik Ngaisyah, thank God it is the wife I have hoped for. She is a woman whose parents apparently have prepared her to become the wife of a priyayi mumpuni (means: capable of doing job well), complete with skill. In the kitchen, she does not only know how to cook, but also leads the servants in the kitchen. Her leadership authority in the work of managing the house is very noticeable (Kayam, 2000, 45).

Dik Ngaisyah, (ah, sudah berapa lama nama itu tidak pernah saya sebut lagi) memang istri saya yang cerdas (Kayam, 20005, : 83).

Dik Ngaisyah, (ah, how long have I never mentioned that name again) it is indeed my wife who is smart (Kayam, 2000: 83).

Even though Ngaisyah was only a housewife, she wasportrayed as a woman with authority, especially in leading the household. As a husband, Sastrodarsono was very grateful to be married with a child of Javanese elite people who had been equipped with the knowledge to be a good wife since childhood. Besides that, Ngaisyah was a smart and reliable wife. Whatever Ngaisyah did, especially in managing the household, she really helped Sastrodarsono.

The paternalistic Javanese culture makes man have a special position, one of which is to become a leader in the family (Handayani \& Novianto, 2004: 179). The result of this culture causes difficulties for women in finding their existence. However, the character Ngaisyah in the novelPriyayi by Umar Kayam can make efforts to make her seen as a superior being. Her role as a 
housewife does not weaken her existence in the family. Javanese women are depicted as powerful figures (Carey \& Houben, 2018: 5). This can be seen clearly in the illustration of the novel Para Priyayi by Umar Kayam that apart from being led, Javanese women are also able to lead even though in the domestic. Based on Suryadi's research (2019: 28) Javanese women are likened to lading, which means that in fostering households, Javanese women must have a empan papan, which means that as women they must be able to position themselves. A woman must be able to place herself with children to be firm, and when with her husband and parents, she must be gentle. According to the view of Javanese culture, powered women tend to be sympathy, care for others, and understand each other ((Toni, 2019: 149).

The existence of Javanese women in the novel Para Priyayi by Umar Kayam is also shown by the character Mbok Yem. Mbok Yem's character in the novel is depicted as an independent woman. Mbok Yem's independence can bring out her identity as a woman in a patriarchal society. Beauvoir believes that the key to liberty for women is to become independent women (Tong transleted by Prabasmoro, 1998: 275).

Embok yang menjajakan tempenya dari rumah ke rumah akhirnya juga sampai di rumah Jalan Satenan itu (Kayam, 2005, : 11).

Embok(means: mom) sellstempe from house to house, finally arrived at Jalan Satenan house (Kayam, 2000: 11).

Saya ingat bagaimana melelahkan berjalan mengawani Embok menjaja tempe itu (Kayam, $2005,: 13)$.

I remember how tiring walking around Embok selling tempe was (Kayam, 2000: 13).

After her husband's death, Mbok Yem became the backbone of the family to funding her family. Mbok Yem became a tempe seller around the village tovillage to sell their goods. The proceeds from the sale of tempe were used by Mbok Yem to funding his daily life and as expenses for sending his son to school, namely Lantip. According to Lantip, hisembokwas a mother who is firm and good at economizing.

Besides, Javanese women have smooth, calm, silent and calm characters:they also have a strong physical endurance (Handayani \& Novianto, 2004: 130). This physical endurance can help Javanese women to create an identity for them that they are not weak creatures. Mbok Yem's decision to become a Tempe seller after her husband died is one of her efforts to become an independent woman. Even though Lantip was adopted as a child by a Priyayi (means: elite people) family, it did not make Mbok Yem stop selling Tempe. This proves that women are not only inferior beings but also superior beings.

Besides Ngaisyah and Mbok Yem, women's efforts to show their existence as a result of the patriarchal culture were also shown by Soemini. As the only daughter in the family, Soemini was very much cared for by her family, especially her parents. Sastrodarsono, as Soemini's father, strongly adheres to the patriarchal culture, so that all decisions depended on him. Sastrodarsono wanted his daughter to get married after she finished junior high school at HIS. However, Soemini refused because she wanted to continue her studies and achieve his goals. 
Saya mau sekolah dulu di Van Deventer School. Selesai itu baru saya bersedia jadi istri Kamas Harjono (Kayam, 2005: 78).

I want to go to school Van Deventer School. After that, I will be ready to be Kamas Harjono's wife (Kayam, 2000: 78).

Pertimbangan saya, Bu, Pak. Saya merasa belum siap. Kalau tamat HIS ini nanti saya baru lima belas tahun umur saya. Bukankah kita termasuk keluarga priyayi maju pengikut pikiran Raden Ajeng Kartini yang tidak setuju perempuan kawin terlalu muda. Juga saya ingin menambah pengetahuan dan inginmerasakan sekolah di kota yang lebih besar dari Wanagalih. Sekolah ke Solo atau ke mana begitu (Kayam, 2005: 79).

My consideration, madam, sir. I am not ready. When I finish HIS, I will be fifteen years old. Aren't we advanced priyayi families, followers of Raden Ajeng Kartini's thoughts who don't agree that women marry too young? Also I want to increase my knowledge and want to experience school in a advanced city than Wanagalih, going to school to Solo or elsewhere (Kayam, 2000: 79).

Soemini was a female figure who has advanced thinking. She wanted to continue her studies to a high level, but it was opposed by Sastrodarsono.Sastrodarsono had the intention to match Soemini after she graduated from junior high school. Soemini refused because she had the willpower to continue high school and after that she wanted an arranged marriage with a man her parents chose.

The position of women in patriarchal culture is below men, including in the family. Besides his obligation to earn a living, the father has a major role in managing the family as the head of the household. So, the words and actions of the head of the household must be obeyed. Early doctrine women do not need high school because in the end they will be mothers and wives who have been embedded in a patriarchal society.Sudarso et al., (2019: 9)stated in his research that in coastal Java, to be exact, women in Madura experience marginalization due to social and cultural structures. Low education and early marriage occur because of this. One of the efforts to achieve women's liberty is when women become intellectuals (Tong transleted by Prabasmoro, 1998: 274). The action that Soemini took refused to be matched because she wanted school to be an attempt by Javanese women to gain her freedom within the grip of a patriarchal culture.

\section{Conclusion}

Based on the analysis above, it was found that there are injustices experienced by Javanese female characters in the novel Para Priyayi by Umar Kayam. This injustice was due to the patriarchal culture inherent in Javanese society, made it difficult for women to bring out their existence in society. The impact of the patriarchal culture was experienced by Ngaisyah, who was labelled by her own husband that she had to be a good mother and wife. In addition, there were figures from Mbok Yem and Soemini who experienced the impact of patriarchal culture. Due to a social construction that placed men above social women, it was difficult for women to express their opinions. Javanese female characters in the novel Para Priyayi by Umar Kayam make efforts, so that they could find their identity in society and family by becoming independent women and intellectual women. Ngasiyah was a wife and housewife who could not only be macak, manak, and masak (means: applying makeup, giving birth, and cooking), but she could also be a leader in household. Meanwhile, Mbok Yem was an independent woman and Soemini was an intellectual woman. 


\section{References}

Asri, Y. (2014). The Representation of Javanese Women's Rejection Toward Patriarchy Ideology A Study of Existential Feminism Toward Rara Mendut Novel By Yb. Mangunwijaya. Valley International Journal.1(6), 446-457.

Bennett, A., \& Royle, N. (2016). An introduction to literature, criticism and theory. In An Introduction to Literature, Criticism and Theory. Edinburgh Gate: Pearson Longman. https://doi.org/10.4324/9781315652450

Budiati, A. C. (2010). Aktualisasi Diri Perempuan Dalam Sistem Budaya Jawa (Persepsi Perempuan terhadap Nilai-nilai Budaya Jawa dalam Mengaktualisasikan Diri). Pamator. 3(1), 51-59.

Carey:, \& Houben, V. (2018). Perempuan-Perempuan Perkasa di Jawa Abad XVIII-XIX. Jakarta: KPG (Kepustakaan Populer Gramedia.

De Beauvoir, S. (1949). The Childhood. In The second sex: Vol. II. The Second Sex. Transleted by Constance Borde dan Sheila Molvany Chevallier 2010. New York: Vintage Books

Handayani, C. S., \& Novianto, A. (2004). Kuasa Wanita Jawa (1st ed.). Yogyakarta: LKiS Yogyakarta.

Pranowo, Y. (2013).Identitas Perempuan dalam Budaya Patriarkis: Sebuah Kajian tentang Feminisme Eksistensialis Nawal el Sa'adawi dalam Novel "Perempuan di Titik Nol. Melintas 29(1), 56-78. https://doi.org/10.26593/mel.v29i1.266.56-78

Kayam, U. (2000). Para Priyayi. Bandung: Pustaka Utama Grafiti.

Kurnianto, E. A. (2016). Ketidakberdayaan Perempuan Atas Persoalan Kehidupan Dalam Novel Garis Perempuan Karya Sanie B. Kuncoro. Aksara. 28(2), $157-$ 170https://doi.org/10.29255/AKSARA.V28I2.128.157-170

Medhidhammaporn:(1995). Sartre's Existentialism And Early Buddhism A Comparative Study Of Selflessness Theories. Bangkok: Buddhadhamma Foundation.

Miles, M. B., Huberman, A. M., \& Saldana, J. (2014). Qualitative Data Analysis: A Methods Sourcebook. Third Edition. Singapore : SAGE publcation https://doi.org/10.1177/239700221402800402

Nurgiyantoro, B. (2015). Teori Pengkajian Fiksi (11th ed.). Gadjah Mada University Press.

Putri, A., \& Nurhajati, L. (2020). Representasi perempuan dalam kukungan tradisi Jawa pada f film Kartini karya Hanung Bramantyo. ProTVF. 4(1) https://doi.org/10.24198/ptvf.v4i1.24008

Rokhimah, S. (2014). Patriakhisme dan Ketidakadilan Gender. Muzawah. 6(1), 132-145.

Rosemarie Phutnam Thong, \& Prabasmoro, penerjemah: A. P. (1998). Feminist Thought: Pengantar Paling Komperhensif kepada Arus Utama Pemikiran Feminisme (Kurniasih (Ed.): Second Edi). Jakarta: Jalasutra.

Sakina, A. I., \& A., D. H. S. (2017). Menyoroti Budaya Patriarki Di Indonesia.Share: Social Work Journal. https://doi.org/10.24198/share.v7i1.13820 
Sudarso, Philipus E, Siti M. 2019. Gender, Religion and Patriarchy: The Educational Discrimination of Coastal Madurese Women, East Java. Journal of International Women's Studies. 20(9), 1-12

Suryadi, M. (2019). Potret Kekuatan Perempuan Jawa dalam Bingkai Peralatan Tradisional Masyarakat Jawa Pesisir Melalui Analisis Peran Semantis. Nusa: Jurnal Ilmu Bahasa Dan Sastra. 14(1), 22-32 https://doi.org/10.14710/nusa.14.1.22-32

Tong, R. (2018). Feminist thought: A more comprehensive introduction. In Feminist Thought, Student Economy Edition: A More Comprehensive Introduction. Boulder: Westview Press. https://doi.org/10.4324/9780429493836

Toni, A. (2019). Wacana Kepemimpinan Perempuan Dalam Film 'Opera Jawa' Karya Garin Nugroho. KOMUNIKA: Jurnal Dakwah Dan Komunikasi. 13(2), 137-152 https://doi.org/10.24090/komunika.v13i2.2072

Tsany, F. (2017). Trend Pernikahan Dini di Kalangan Remaja (Studi Kasus Di Kabupaten Gunung Kidul Yogyakarta Tahun 2009-2012). Jurnal Sosiologi Agama. 9(1) https://doi.org/10.14421/jsa.2015.09105

UNICEF Indonesia, UI, S. I. (BPS) P., \& Bappenas, K. P. (2020). Child Marriage in Indonesia Latest statistics of child marriage in Indonesia. Badan Pusat Statistik.

Urifatulailiyah, N. (2016). Pemikiran Pendidikan Perempuan Pribumi Jawa Dalam Pers Kolonial Tahun 1908-1928. Avatara, 5(1), 1481-1494.

Walby, S. (1990). Theorizing Patriarchy. Cambrigde: Basic Blackwell.

Wiyatmi, W. (2010). Citraan Perlawanan Simbolis Terhadap Hegemoni Patriarki Melalui Pendidikan dan Peran Perempuan di Arena Publik dalam Novel-Novel Indonesia. ATAVISME. 13(2) https://doi.org/10.24257/atavisme.v13i2.135.243-256

\section{Copyrights}

Copyright for this article is retained by the author(s), with first publication rights granted to the journal.

This is an open-access article distributed under the terms and conditions of the Creative Commons Attribution license (http://creativecommons.org/licenses/by/4.0/). 